\title{
EFFECTS OF DEFOLIATION BY SPRUCE BUDWORM (CHORISTONEURA FUMIFERANA CLEM.) ON RADIAL GROWTH AT BREAST HEIGHT OF BALSAM FIR (ABIES BALSAMEA (L.) MILL.) AND WHITE SPRUCE (PICEA GLAUCA (MOENCH) VOSS.) ${ }^{1}$
}

\author{
By J. R. BLAIS ${ }^{2}$
}

\section{ABSTRACT}

The relationship between spruce budworm defoliation and radial growth at breast height for balsam fir and white spruce trees of merchantable size was studied in various stands in northwestern Ontario. Defoliation was recorded yearly for these stands from the beginning of the infestation, and radial growth measurements were obtained from increment cores. The first year of radial growth suppression was calculated by comparing the growth of the affected species with that of jack pine and red pine trees by means of a growth-ratio technique. Apparent suppression in balsam fir and white spruce varied between stands, and, generally, occurred at the earliest in the second year and at the latest in the fourth year of severe defoliation. $A$ wide ring at the base of the tree coinciding with the first year of suppression as reported by Craighead was non-existent.

\section{INTRODUCTION}

The spruce budworm feeds almost exclusively on the current year's growth of balsam fir and white spruce, but populations of this insect sometimes reach such proportions that the larvae feed to some extent on old foliage (Swaine et al., 1924; Balch et al., 1954). However, in the recent infestations in northwestern Ontario, feeding on old foliage was uncommon. Five to eight years of repeated destruction of the current year's growth results in the death of the tree (Belyea, 1952).

Defoliation of even part of the foliage of some species of deciduous trees causes a reduction in concurrent radial growth (Dils and Day, 1950). In conifers, however, reduction in radial growth does not usually coincide with the first year of defoliation. Reeks and Barter (1951) found that defoliation by the European spruce sawfly (Gilpinia hercyniae (Htg.)) caused a gradual reduction in the width of the annual ring of white spruce throughout the stem and that this was greater in the lower part. Loss of 20 to 50 per cent of the old foliage was necessary to cause measurable reduction in the ring width. Preliminary studies by the author (1954) indicated that repeated severe defoliation of white spruce by the spruce budworm did not appear to be reflected in any reduction in radial increment at breast height during the first three or four years. Belyea (1952) mentions that the first suppression of radial increment at breast height in balsam fir occurred about two years following the first year of severe defoliation by the spruce budworm. Records obtained by Webb (1955)

\footnotetext{
${ }^{1}$ Manuscript received May 6, 1957. Contribution No. 392, Forest Biology Division, Science Service, Department of Agriculture, Ottawa, Canada.

Forest Biology Laboratory, Quebec, Quebec, Biographic reference Forestry Chronicle, Vol. 33 : 364.
} 
show that the first year of radial growth suppression at breast height of balsam fir in New Brunswick occurred in the fourth year of severe defoliation by the spruce budworm.

The present studies were undertaken in the Lac Seul infestation in northwestern Ontario to clarify the relationship between defoliation by spruce budworm and reduction in the radial growth of balsam fir and white spruce of merchantable size, and to determine some of the other effects of defoliation on radial increment. Turner (1952) found that the reduction in radial growth in the basal part of the tree occurred one to two years later than in the top. In the present study all observations were made at breast height, the type 2 sequence described by Duff and Nolan (1953) being used exclusively.

\section{MeTHods}

Radial growth measurements were obtained from balsam fir and white spruce trees growing in stands where the defoliation of balsam fir had been recorded yearly since the start of the infestation. In each of 6 plots scattered over a territory of approximately 300 square miles, defoliation records were made on approximately 60 marked trees of merchantable size distributed along lines from one-quarter to one-half mile in length, in mature and overmature stands. Each tree was described as to total height, diameter at breast height, crown height, width and class. Defoliation of the current year's growth was estimated by the same person every year, using binoculars, and was classified in the following percentages: $0,10,25,50,75,90$, and 100 . Two or three trees were felled each year in each plot for more critical examination of the foliage. Although defoliation records were not obtained directly for white spruce, defoliation of this species, though somewhat less, varied little from that of balsam fir.

Measurements of radial growth were obtained from increment cores. Three cores distributed approximately along trisecting radii were taken at breast height from each of 50 trees of merchantable size of each species in each plot. Cores were taken in September, when radial growth for the current

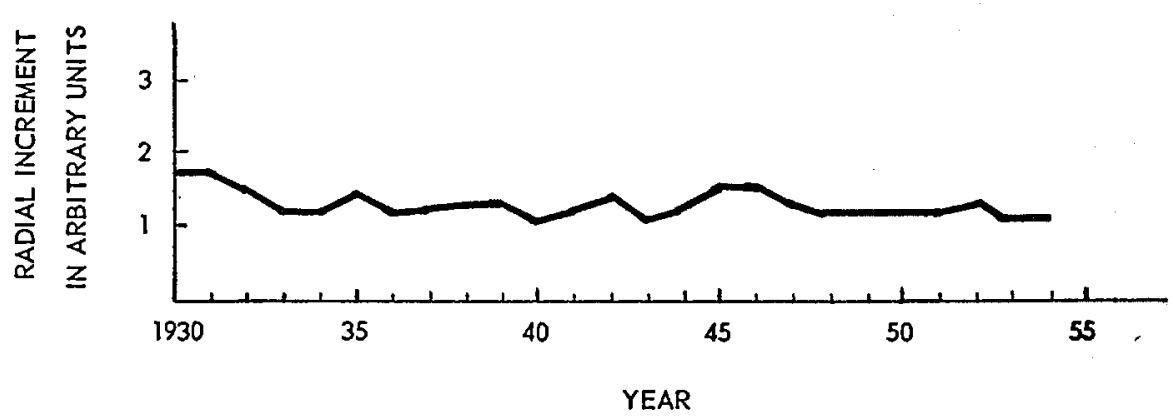

FIGURE 1: Average yearly radial growth from 1930 to 1954 for all pines for plots 1, 2, 3, and 4 . 
$\Delta$ First year of defolidtion

A First yoar of severe defoliation

$\downarrow$ First yoor of rodial growth suppression of breast height

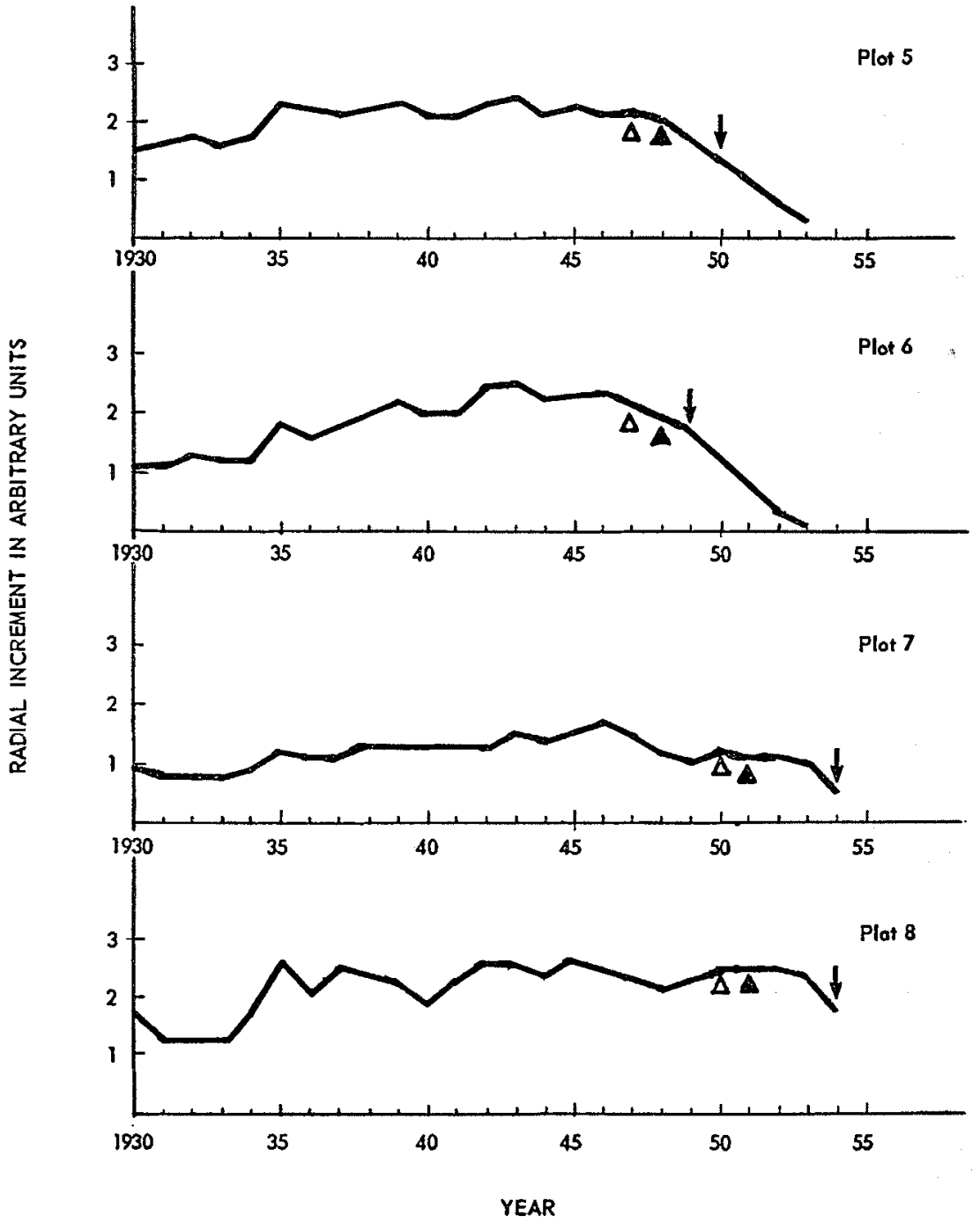

FIGURE 2: Average yearly radial growth at breast height from 1930 to 1954 for balsam fir for plots $5,6,7$, and 8 . 
year was completed. Defoliation and growth measurements were not necessarily taken from the same trees; the object was to establish plot averages.

Because of severe defoliation over most of the study area, it was impossible to find undefoliated balsam fir and white spruce trees to use as controls. Two tree species not generally affected by the spruce budworm, jack pine (Pinus banksiana Lamb.) and red pine (Pinus resinosa Ait.), were used as controls. Many jack pine stands in this region were affected by the jack pine budworm (Choristoneura pinus Free.) from 1937 to 1940, but the outbreak was confined largely to stands 40 years of age and older (Richmond, 1941). The jack pine trees used in the present study were all less than 40 years old at the time of the jack pine budworm epidemic. Although radial growth in jack pine showed a slight reduction in 1940, radial growth in balsam fir was also reduced that year (Figure 2). The radial growth of the sampled jack pine trees was apparently not affected by any defoliation that might have occurred from 1937 to 1940 . Red pine is not usually attacked by the jack pine budworm, and any fluctuations in the radial growth of this species can be attributed to climatic conditions.

The rings from 1930 to the last year of growth (1953 or 1954, according to the year the cores were obtained) were measured with the aid of a binocular microscope equipped with an ocular micrometer. The yearly average for each species in each plot was based on the three cores from each of the 50 trees sampled.

\section{RESULTS}

Jack pine was sampled in plots 1,2 , and 3; red pine in plot 4 ; balsam fir in plots $5,6,7$, and 8 ; and white spruce in plots $5,6,9$, and 10 .

\section{TABLE I}

Yearly Defoliation by the Spruce Budworm of the Current Year's Growth of Balsam Fir in the Sample Plots

\begin{tabular}{rrrrrrrrrrrr}
\hline \multirow{8}{*}{ Plot } & \multicolumn{10}{c}{ Average per cent defoliation of the current year's growth } \\
\cline { 2 - 12 } No. & $\mathbf{1 9 4 5}$ & $\mathbf{4 6}$ & $\mathbf{4 7}$ & $\mathbf{4 8}$ & $\mathbf{4 9}$ & $\mathbf{5 0}$ & $\mathbf{5 1}$ & $\mathbf{5 2}$ & $\mathbf{5 3}$ & $\mathbf{5 4}$ \\
\hline $\mathbf{5}$ & 0 & 0 & $10-25$ & 100 & 100 & 100 & 100 & 100 & 100 & 100 \\
$\mathbf{6}$ & 0 & 0 & $10-25$ & 100 & 100 & 90 & 100 & 100 & 90 & 100 \\
7 & 0 & 0 & 0 & 0 & 0 & $10-25$ & $75-90$ & 100 & 100 & 100 \\
8 & 0 & 0 & 0 & 0 & 0 & 0 & 75 & 100 & 100 & 100 \\
9 & 10 & 75 & 100 & 100 & 75 & 100 & 100 & 10 & 25 & 100 \\
10 & 10 & 75 & 100 & 100 & 75 & 100 & 100 & 75 & 10 & 90 \\
\hline
\end{tabular}

Table I shows the yearly defoliation of the current year's growth of balsam fir in the sample plots. Defoliation of the current year's growth between balsam fir trees of merchantable size within plots was very uniform, and, with the exception of the first year, was close to 100 per cent for most years. In plots where defoliation recurred for the greatest number of years, tree mortality was fairly extensive at the time of this study.

The growth pattern for jack pine trees in each of the three plots and for red pine trees in one plot was very similar. Figure 1 shows the average yearly radial growth for all pines for all plots, from 1930 to 1954. 
Figure 2 shows the yearly radial growth from 1930 to 1954 for balsam fir from plots $5,6,7$, and 8. The first year of light defoliation (10 to 25 per cent destruction of the current year's growth) and of heavy defoliation ( 75 to 100 per cent destruction of the current year's growth) are shown.

In order to determine the first year of radial growth suppression due to budworm defoliation, growth ratios were used. These were obtained by dividing the average annual growth of the affected species by the average annual growth of the pines. Since all tree species tend to respond in a similar fashion to climatic variation, growth fluctuations occasioned by climate were minimized and the reduction in radial growth of white spruce and balsam fir through continued defoliation was made more evident. The apparent first year of radial growth suppression was considered to be the one showing a growth ratio less than that of any of the preceding years, followed by a series of declining ratios. By using the average growth for all trees in one plot to calculate the yearly growth ratios, it is the first year of suppression common to the greatest number of trees in that plot that is brought in evidence. In each plot, the first year of suppression for some trees occurred earlier or later than that for the greatest number. When growth ratios for each of the fifty balsam fir trees sampled in plot 5 were calculated (by dividing the yearly radial growth of individual trees by the average yearly growth of the pines), the first year of suppression occurred in $1948,1949,1950$, and 1951 for $2,12,23$, and 13 trees respectively. In the present study, collective trees of merchantable size rather than individual trees are being considered, and the first year of radial growth suppression in any one plot refers to the first year of suppression common to the greatest number of trees in that plot.

Table II shows the annual growth ratios for balsam fir from 1940 to 1953 for plots 5 and 6, and from 1940 to 1954 for plots 7 and 8 . The first series of ratios was calculated by dividing the average yearly growth of balsam fir in each of the four balsam fir plots by the average yearly growth of the pines for the same years. Since the spruce budworm did not attack the trees in plots 7 and 8 until 1950 , the balsam fir in these plots can also serve as controls for plots 5 and 6 until that year and, as such, are possibly even more reliable than the pines. The second series of ratios in Table II was calculated by dividing the actual growth per year of the balsam fir in each of plots 5 and 6 by the combined average yearly growth of the balsam fir in plots 7 and 8 . In plot 5 , the growth ratios for 1950 based both on pines and on balsam fir in plots 7 and 8 were less than those of any preceding year, and were followed by series of declining ratios. Therefore, according to this criterion, 1950, the third year of severe defoliation, was the apparent first year of radial growth suppression at breast height of balsam fir in this plot. In plot 6 , both series of growth ratios indicate that 1949, the second year of severe defoliation, was the apparent first year of radial growth suppression. In plots 7 and 8, 1954 was the first year in which balsam fir growth was noticeably out of phase with that of the pines. Defoliation in these two plots was fairly similar, being somewhat more severe in the initial years in plot 7 than in plot 8 (Table I). In both plots, the apparent first year of radial growth suppression at breast height occurred in the fourth year of severe defoliation. 
TABLE II

Yearly Growth Ratios for Balsam Fir From 1940 to 1953 for Plots 5 and 6, AND From 1940 to 1954 for Plots 7 and 8. UNDERLINED Ratios Indicate First Year of Suppression

\begin{tabular}{lcccccc}
\hline \multirow{2}{*}{ Year } & \multicolumn{3}{c}{ Ratios based on } & \multicolumn{2}{c}{ growth of pines } & \multicolumn{3}{c}{$\begin{array}{c}\text { Ratios based on grawth of } \\
\text { balsam fir in plots 7 and 8 }\end{array}$} \\
\cline { 2 - 7 } & Plot 5 & Plot 6 & Plot 7 & Plot 8 & Plot 5 & Plot 6 \\
\hline 1940 & 1.91 & 1.82 & 1.18 & 1.73 & 1.31 & 1.54 \\
1941 & 1.75 & 1.67 & 1.08 & 1.92 & 1.17 & 1.11 \\
1942 & 1.64 & 1.71 & 0.93 & 1.86 & 1.15 & 1.20 \\
1943 & 2.18 & 2.27 & 1.35 & 2.36 & 1.20 & 1.25 \\
1944 & 1.75 & 1.83 & 1.17 & 2.00 & 1.10 & 1.16 \\
1945 & 1.47 & 1.53 & 1.00 & 1.80 & 1.00 & 1.09 \\
1946 & 1.40 & 1.53 & 1.13 & 1.67 & 1.00 & 1.09 \\
1947 & 1.61 & 1.69 & 1.15 & 1.85 & 1.10 & 1.16 \\
1948 & 1.67 & 1.58 & 1.00 & 1.83 & 1.18 & 1.12 \\
1949 & 1.42 & 1.42 & 0.92 & 1.92 & 1.00 & 1.00 \\
1950 & $\underline{1.17}$ & 1.00 & 1.00 & 2.08 & 0.77 & 0.66 \\
1951 & 0.83 & 0.67 & 0.92 & 2.08 & 0.55 & 0.44 \\
1952 & 0.46 & 0.31 & 0.85 & 1.92 & 0.33 & 0.22 \\
1953 & 0.27 & 0.09 & 1.10 & 2.18 & & \\
1954 & & & $\underline{0.45}$ & $\underline{1.64}$ & & \\
\hline
\end{tabular}

Figure 3 shows the annual growth from 1930 to 1954 for white spruce trees in plots $5,6,9$, and 10 . The first years of light and heavy defoliation by the spruce budworm are indicated for each of the plots.

Table III shows the growth ratios for white spruce from 1940 to 1953 for plots $5,6,9$, and 10 . The average annual growth of the spruce trees for each plot was divided by the average annual growth of the pines for the first series of ratios, and by the average annual growth of the balsam fir in plots 7 and 8 for the second series. In plots 5 and 6 both series of ratios indicate that apparent radial growth suppression at breast height in white spruce first occurred in 1949 , the second year of severe defoliation. In plot 9, the first apparent suppression occurred in 1948, the third year of severe defoliation. In plot 10 , interpretation of the first year of suppression presents some difficulty. According to the criterion adopted, 1949 is the first year that showed the effects of defoliation, since the growth ratio for that year was appreciably lower than that of any of the preceding years. However, if the growth ratio in 1944 had not been depressed, owing apparently to differential effects of climate on white spruce as contrasted with the pines and balsam fir, one might reasonably have selected 
$\Delta$ First yeor of dofoliation

A First yoor of severo defoliatian

First yous of radial growth suppression at breast height

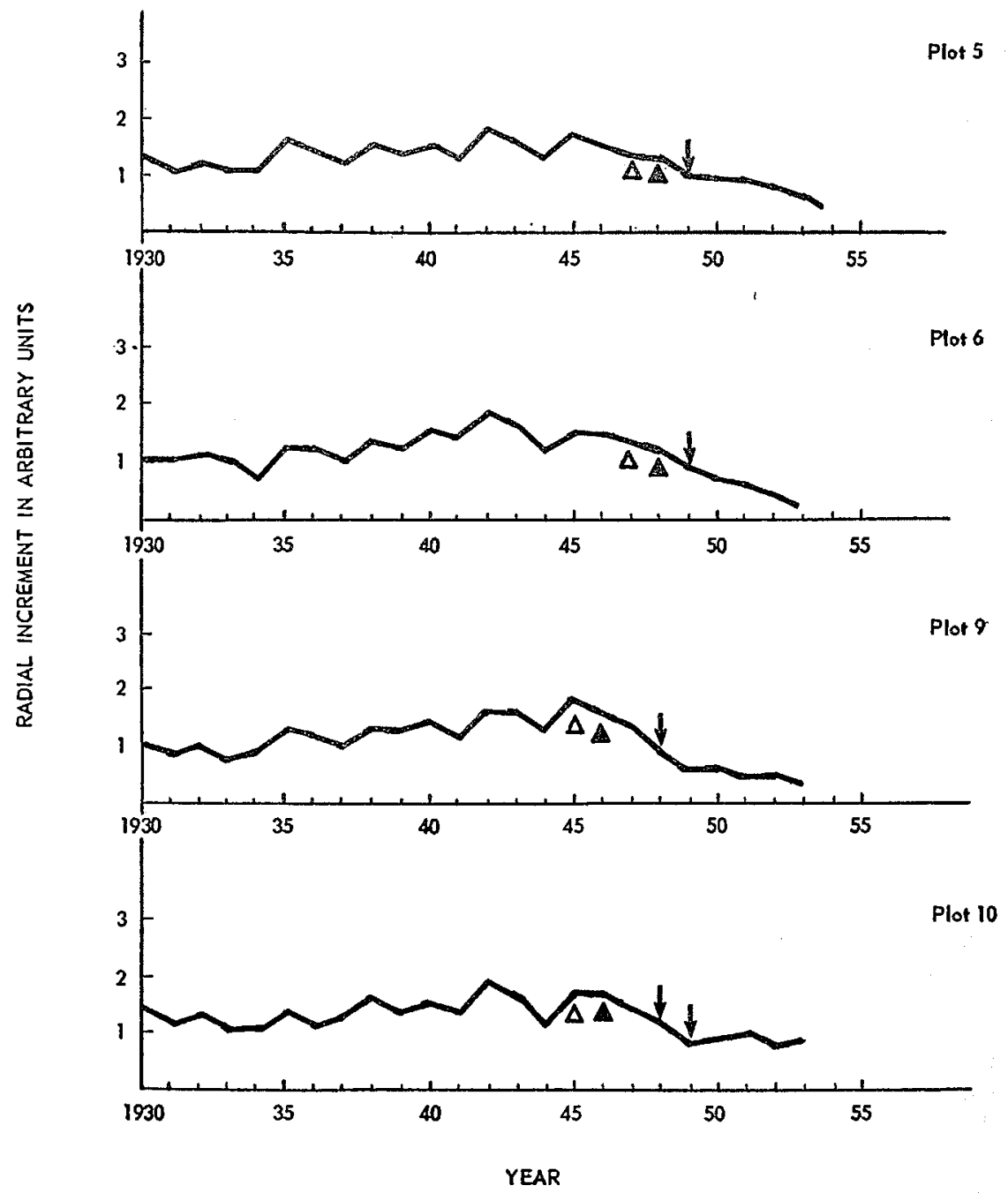

FIGURE 3: Average yearly radial growth at breast height from 1930 to 1954 for white spruce for plots 5, 6, 9, and 10 . 
1948 as the first year showing the effects of defoliation. Therefore in plot 10 , initial radial suppression of white spruce at breast height occurred either in the third or the fourth year of continued severe defoliation. The radial growth pattern in this plot was exceptional in that the apparent first year of suppression was followed by fluctuations in growth rather than by a continued decline.

TABLE III

Yearly Growth Ratios for White Spruce from 1940 to 1953 For Plots 5, 6, 9, AND 10. UNDERLINED

Ratios INDICATE FIrST YEaR OF SUPPRESSION

\begin{tabular}{lllllllllr}
\hline \multirow{2}{*}{ Year } & \multicolumn{3}{c}{ Ratios based on growth of pines } & \multicolumn{3}{c}{$\begin{array}{c}\text { Ratios based on growth of } \\
\text { balsam fir in plots 7 and 8 }\end{array}$} \\
\cline { 2 - 10 } & Plot 5 & Plot 6 & Plot 9 & Plot 10 & Plot 5 & Plot 6 & Plot 9 & Plot 10 \\
\hline 1940 & 1.36 & 1.36 & 1.27 & 1.36 & 0.94 & 0.94 & 0.87 & 0.94 \\
1941 & 1.08 & 1.17 & 1.00 & 1.17 & 0.72 & 0.78 & 0.67 & 0.78 \\
1942 & 1.28 & 1.28 & 1.14 & 1.05 & 0.90 & 0.90 & 0.80 & 0.95 \\
1943 & 1.45 & 1.45 & 1.45 & 1.54 & 0.80 & 0.80 & 0.80 & 0.85 \\
1944 & 1.08 & 1.00 & 1.08 & 1.00 & 0.68 & 0.63 & 0.68 & 0.63 \\
1945 & 1.13 & 1.00 & 1.20 & 1.13 & 0.81 & 0.71 & 0.86 & 0.81 \\
1946 & 1.00 & 1.00 & 1.07 & 1.13 & 0.71 & 0.71 & 0.76 & 0.81 \\
1947 & 1.00 & 1.00 & 1.08 & 1.15 & 0.68 & 0.68 & 0.74 & 0.79 \\
1948 & 1.08 & 1.00 & 0.75 & 1.00 & 0.76 & 0.70 & 0.53 & 0.70 \\
1949 & 0.83 & 0.67 & 0.50 & 0.67 & 0.59 & 0.47 & 0.35 & 0.47 \\
1950 & 0.75 & 0.50 & 0.50 & 0.75 & 0.50 & 0.39 & 0.33 & 0.50 \\
1951 & 0.75 & 0.50 & 0.42 & 0.83 & 0.50 & 0.33 & 0.28 & 0.55 \\
1952 & 0.61 & 0.31 & 0.38 & 0.61 & 0.44 & 0.22 & 0.28 & 0.44 \\
1953 & 0.54 & 0.18 & 0.36 & 0.82 & & & & \\
\hline
\end{tabular}

\section{Discussion and CONClusions}

In balsam fir and white spruce of merchantable size, radial growth at breast height is not suppressed during the first year of defoliation by the spruce budworm, nor even in the first year of severe defoliation. In northwestern Ontario, apparent radial growth suppression in these two species generally occurred at the earliest in the second year, and at the latest in the fourth year of severe defoliation. Therefore, the first year of radial growth suppression at breast height does not follow a fixed degree of defoliation, but varies from one locality to another and from year to year. This is understandable in view of the many variables that affect tree growth, such as vigor, age, and site quality, and of the many variables that affect budworm populations such as stand composition, weather, and the production of flowers on balsam fir. In the present study no attempt was made to isolate these variables. There is one instance, however, where the influence of tree vigor might be assessed from the data at hand. The balsam fir trees in plot 7 were less vigorous than those in plot 8 , the average 
radial growth between 1936 and 1945 for the trees in plots 7 and 8 being 1.3 $\mathrm{mm}$. and $2.4 \mathrm{~mm}$. respectively. In both plots, the trees were subjected to fairly similar defoliation and, irrespective of the difference in tree vigor, apparent suppression occurred in the fourth year of severe defoliation. It should be noted, however, that relative to previous growth the suppression in plot 7 was much greater than in plot 8 .

Craighead (1925) suggests that during the first year of budworm attack on both spruce and balsam fir, there is a severe reduction in radial growth in the upper portion of the trunk, and a widening of the ring in the base of the tree. Although white spruce trees in plots 9 and 10 showed relatively wide rings in the base of the trunks for 1945 and 1946 (the first years of defoliation in these plots), unusually wide rings were also produced in the pines during these two years. Therefore, the wide rings in the spruce may be attributed to favorable growing conditions rather than to defoliation (Figure 3 ). In all other plots, radial growth of the balsam fir and white spruce trees showed no evidence of a wide ring in the basal portion of the tree during the first year of budworm feeding.

\section{ACKNOWLEDGMENT}

Dr. M. L. Prebble, Chief Forest Biology Division, and Dr. R. M. Belyea, Officer in Charge of the Sault Ste. Marie Laboratory, very kindly reviewed the manuscript and provided helpful suggestions.

\section{REFERENCES}

1. BALCH, R. E., F. E. WEBB, and R. F. MORRIS. Results of spraying against spruce budworm in New Brunswick. Can. Dept. Agr. Forest Biol. Div. Bi-mon. Prog. Rept. 10 (1) 1954.

2. BELYEA, R. M. Death and deterioration of balsam fir weakened by spruce budworm defoliation in Ontario. Jour. Forestry, 50: 729-738, 1952.

3. BLAIS, J. R. The recurrence of spruce budworm infestations in the past century in the Lac Seul area of northwestern Ontario. Ecology 35:62-71, 1954.

4. CRAIGHEAD, F. C. Relation between mortality of trees attacked by the spruce budworm and previous growth. J. Agr. Res. 30: 542-555, 1925.

5. DILS, R. E., and M. W. Day. Effect of defoliation upon the growth of aspen. Michigan Agr. Expt. Sta. Quart. Bull. 33: 111-113, 1950.

6. DUFF, G. H. and N. J. NOLAN. Growth and morphogenesis in the Canadian forest species. I. The Controls of cambial and apical activity in Pinus resinosa Ait. Can. Jour. Bot. 31 : 471-513, 1953.

7. REEKS, W. A., and G. W. BARTER. Growth reduction and mortality of spruce caused by the European spruce sawfly. For. Chron. 27: 140-156, 1951.

8. RICHMOND, H. A. Biological control and fluctuation of jack pine budworm population. Annual Technical Report Forest Insect Laboratory, Winnipeg. Unpublished. 1941.

9. SWAINE, J. M., F. C. CRAIGHEAD, and J. W. BAILEY. Studies on the spruce budworm Cacoecia fumiferana Clem. Canada Dept. Agr. Tech. Bull. 37 (N.S.)

10. TURNER, K. B. The relation of mortality of balsam fir, Abies balsanca (L.) Mill., caused by the spruce budworm Choristonetra fumiferana (Clem.), to forest composition in the Algoma forest of Ontario. Canada Dept. Agr. Publ. 875, 107 pp. 1952.

11. WEBB, F. E. Biological assessment of acrial forest spraying against the spruce budworm in New Brunswick. Part I. Timing of operations 1952-54. For. Chron. 31: 342-352, 1955. 